\title{
Comunidade Microbiana do Solo Cultivado com Pimentão nos Sistemas de Plantio Direto e Convencional Associado ao Manejo de Plantas Daninhas ${ }^{1}$
}

\author{
Soil Microbial Community Cultivated with Peppers in No-Tillage and Conventional Systems \\ Associated with Weed Management
}

\author{
CUNHA, J.L.X.L. ${ }^{2}$, FREITAS, F.C.L. ${ }^{3}$, AMBRÓSIO, M.M.Q. ${ }^{3}$, FONTES, L.O. ${ }^{4}$, NASCIMENTO, \\ P.G.M.L. ${ }^{3}$ e GUIMARÃES, L.M.S. ${ }^{3}$
}

\begin{abstract}
RESUMO - Este trabalho teve como objetivo avaliar a comunidade microbiana do solo cultivado com pimentão (Capsicum annum) nos sistemas de plantio direto e convencional, associado às estratégias de manejo de plantas daninhas. O experimento foi conduzido no esquema de parcelas subdivididas, distribuídas no delineamento experimental em blocos casualizados. Nas parcelas, foram avaliados os dois sistemas de plantio (direto e convencional), e nas subparcelas, três estratégias de manejo de plantas daninhas (cobertura do solo com filme de polietileno, capinas regulares e tratamento sem capinas). Avaliaram-se as médias diárias das temperaturas máximas e mínimas do solo, utilizando-se sensores termopares acoplados a dataloggers, e a comunidade de bactérias, fungos e actinomicetos totais, que foram quantificados em amostras de solo coletadas aos 0, 21, 42, 63, 84 e 105 dias após o transplantio. A comunidade microbiana no solo apresentou a seguinte ordem em termos de população: bactérias > actinomicetos > fungos, com variação entre as diferentes épocas de coleta de amostras ao longo do ciclo da cultura, para todos os tratamentos, sendo influenciada pelos sistemas de preparo do solo e manejo de plantas daninhas. O revolvimento do solo no plantio convencional reduziu a população de microrganismos por ocasião do transplantio, em relação ao plantio direto. A cobertura do solo com palhada no sistema de plantio direto ou com plantas daninhas nos dois sistemas de plantio reduziu o aquecimento do solo em relação aos tratamentos com solo mantido sem cobertura, por meio de capinas, e com cobertura com filme de polietileno, proporcionando melhores condições para o desenvolvimento de fungos, bactérias e actinomicetos.
\end{abstract}

Palavras-chave: Capsicum annum, cobertura morta, filme de polietileno, microrganismos no solo.

ABSTRACT - This work aimed to evaluate the soil microbial community cultivated with sweet pepper (Capsicum annum) in no-tillage and conventional systems associated with weed management strategies. The experiment was conducted in split plots distributed in a randomized complete block design. Two soil tillage systems were evaluated in the plots (no-tillage and conventional), and three weed management strategies were evaluated in the sub-plots: soil coverage with black polyethylene film, regular weeding and no weeding. The characteristics evaluated were maximum and minimum soil temperatures using thermocouple sensors connected to dataloggers, and the community of total bacteria, fungi and actinomycetes, which were quantified in soil samples collected at 0, 21, 42, 63, 84 and 105 days after transplanting. The soil microbial community presented the following order in terms of population: bacteria> actinomycetes $>$ fungi, with variation between different times of sample collection throughout the crop cycle, for all treatments; it was influenced by tillage systems and weed management. Soil disturbance in conventional tillage system reduced the population of microorganisms at the time of transplanting, compared to the no-tillage system. Coverage of soil with straw mulch in

Recebido para publicação em 11.8.2013 e aprovado em 12.5.2014.

2 Universidade Federal de Alagoas, Maceió-AL, Brasil <cunhajlx@gmail.com>; ${ }^{3}$ Universidade Federal Rural do Semiárido, MossoróRN, Brasil; ${ }^{4}$ Universidade Federal do Ceará, Fortaleza-CE, Brasil. 
no-tillage system or with weeds in both tillage systems reduced soil heating compared to treatments where soil was kept uncovered through weeding or covered with polyethylene film. This provided better conditions for the development of fungi, bacteria and actinomycetes.

Keywords: Capsicum annum, straw mulch, polyethylene film, soil microorganisms.

\section{INTRODUÇÃO}

O solo é um meio natural constituído das frações orgânica e inorgânica (rochas e minerais) e habitado por inúmeras espécies, formando um ecossistema (Andreola \& Fernandes, 2007). Este também tem a função de suprir as necessidades de nutrientes das plantas, servir de suporte físico a elas, promover a movimentação ou retenção da água, suportar as cadeias alimentares e as funções reguladoras do ambiente (Tótola \& Chaer, 2002). Os microrganismos fazem parte do solo de maneira indissociável, sendo responsáveis por inúmeras reações bioquímicas, e atuam ainda como reguladores de nutrientes, favorecendo o crescimento das plantas (Andreola \& Fernandes, 2007).

Os principais fatores que afetam qualitativa e quantitativamente a biomassa microbiana do solo são: disponibilidade e tipo de substrato orgânico, fatores abióticos, como temperatura, umidade e aeração, mineralogia do solo, presença de microrganismos antagonistas, parasitas e predadores e adição de defensivos agrícolas ou metais pesados ao solo (Franchini et al., 2007). Esses fatores podem ser fortemente influenciados por práticas agrícolas.

O plantio direto na palha é uma prática cultural na qual não se faz o revolvimento do solo, mantendo a cobertura morta (palhada) sobre sua superficie. Através dessa técnica, busca-se influenciar positivamente as qualidades físicas, químicas e biológicas do solo, propiciando condições adequadas para o crescimento radicular.

Esse sistema de cultivo reduz a magnitude das oscilações diárias da temperatura do solo, principalmente próximo à superfície, por constituir uma barreira fisica que impede a incidência direta dos raios solares sobre a superficie do solo, reduzindo a taxa de aquecimento (Coelho et al., 2013), e por impedir a transferência de energia e vapor de água para a atmosfera (Gasparim et al., 2005). O plantio direto beneficia também o desempenho das culturas, melhorando a eficiência no uso da água, em consequência do aumento na infiltração e da redução de perdas por evaporação (Teófilo et al., 2012). Além disso, a perturbação minima do solo, apenas na linha de plantio, associada à cobertura deste com palhada reduz a taxa de germinação e emergência de plantas daninhas, reduzindo ou até mesmo evitando a realização de capinas ou uso de herbicidas (Silva et al., 2009; Nascimento et al., 2011; Teófilo et al., 2012).

A cobertura do solo com filme de polietileno tem sido bastante utilizada no controle de plantas daninhas e na redução da perda de água por evaporação no cultivo de hortaliças (Teófilo et al., 2012). No entanto, essa prática eleva a temperatura do solo, tornando-a sempre superior à daqueles sem cobertura (Bonanomi et al., 2008) ou com cobertura morta (Coelho et al., 2013), o que pode apresentar efeitos benéficos ou negativos, dependendo da cultura e das condições ambientais. Segundo Furlani et al. (2008), temperaturas do solo muito altas têm efeitos negativos sobre plântulas e raízes e na atividade microbiana do solo, podendo comprometer também a absorção de nutrientes pelas plantas.

Desse modo, o conhecimento dos efeitos das práticas de manejo agrícola sobre as comunidades microbianas é de extrema importância, devido às inúmeras funções que os microrganismos desempenham no solo, como decomposição da matéria orgânica, ciclagem de nutrientes, associações simbióticas com as raízes das plantas, controle biológico de patógenos, degradação de substâncias tóxicas, solubilização de minerais, entre outras (Stanford et al., 2005). Portanto, o objetivo deste trabalho foi avaliar a comunidade microbiana do solo cultivado com pimentão nos sistemas de plantio direto e convencional em diferentes estratégias de manejo de plantas daninhas. 


\section{MATERIAL E MÉTODOS}

O experimento foi conduzido no município de Mossoró-RN, localizado a $5^{\circ} 11^{\prime \prime}$ de latitude sul e $37^{\circ} 20^{\prime \prime}$ de longitude oeste e $18 \mathrm{~m}$ de altitude, no esquema de parcelas subdivididas, distribuídas no delineamento experimental em blocos casualizados com quatro repetições. Nas parcelas, foram avaliados os sistemas de plantio direto (SPD) e convencional (SPC) e, nas subparcelas, três estratégias de manejo de plantas daninhas (cobertura do solo com filme de polietileno preto, capinas regulares e sem capinas). Vale ressaltar que as áreas de plantio direto e convencional vêm sendo cultivadas há quatro anos nos referidos sistemas com a seguinte sucessão de culturas: feijão-caupi em consórcio com braquiária, melão, milho em consórcio com braquiária, melão, melancia e feijãocaupi, sendo a área de plantio convencional preparada com aração e duas gradagens, e a de plantio direto, dessecada com herbicidas.

Cada subparcela foi composta por três fileiras de $12 \mathrm{~m}$, espaçadas entre si de $0,90 \mathrm{~m}$, com plantas espaçadas de $0,60 \mathrm{~m}$ nas fileiras. Foi considerada área útil a fileira central, descartando-se duas plantas em cada extremidade.

Para a formação da palhada no sistema de plantio direto, utilizou-se a cultura do milho consorciado com Brachiaria brizanta cv. Marandu, semeados em fevereiro de 2010. A semeadura da forrageira foi feita na linha de plantio da cultura do milho, em fileiras espaçadas de $0,60 \mathrm{~m}$, utilizando-se $3,0 \mathrm{~kg} \mathrm{ha}^{-1}$ de sementes viáveis, distribuídas juntamente com o fertilizante $\left(200 \mathrm{~kg} \mathrm{ha}^{-1}\right.$ da formulação N-P-K 06-24-12). Após a colheita do milho, no final do mês de maio, a forrageira cresceu livremente até julho, quando foi realizada dessecação com $1,9 \mathrm{~kg}^{-1}$ de glyphosate; duas semanas após a dessecação, realizou-se o tombamento da palhada com rolo-faca tratorizado. Por ocasião do transplantio das mudas de pimentão, a cobertura morta composta pela palhada da braquiária, juntamente com restos culturais do milho, foi quantificada por meio de amostragens, utilizando o quadrado vazado de $0,5 \mathrm{~m}$ de lado, que foram levadas à estufa com circulação forçada de ar a $65^{\circ} \mathrm{C}$ até massa constante, verificando-se $6,0 \mathrm{t} \mathrm{ha}^{-1}$ de massa seca.
Nas parcelas com plantio convencional, a área foi cultivada com milho em monocultivo no mesmo período das parcelas com plantio direto. O solo foi preparado por meio de uma aração e duas gradagens, realizadas uma semana antes do transplantio das mudas de pimentão.

A implantação do experimento foi feita em setembro de 2010, por meio do transplantio de mudas de pimentão do híbrido Atlantis, produzidas em bandejas de poliestireno expandido, com 200 células, sendo estas transplantadas aos 30 dias após a semeadura.

Da área onde foi conduzido o experimento foram retiradas amostras de solo, classificado como Argissolo Vermelho-Amarelo Eutrófico, na profundidade de 0 a $20 \mathrm{~cm}$, para análises física e química, sendo esta última realizada separadamente para os sistemas de plantio direto e convencional, considerando-se que os solos vêm sendo cultivados nos respectivos sistemas há quatro anos. A análise física revelou a seguinte granulometria: areia total $=0,88 \mathrm{~kg} \mathrm{~kg}^{-1}$, silte $=0,08 \mathrm{~kg} \mathrm{~kg}^{-1} \mathrm{e}$ argila $=0,03 \mathrm{~kg} \mathrm{~kg}^{-1}$. Os resultados das análises químicas dos solos revelaram os seguintes resultados para o sistema de plantio direto: $\mathrm{pH}$ (água) $=6,2$, matéria orgânica $=12,8 \mathrm{~g} \mathrm{~kg}^{-1}, \mathrm{P}=127 \mathrm{mg} \mathrm{dm}^{-3}$, $\mathrm{K}^{+}=160 \mathrm{mg} \mathrm{dm}{ }^{-3}, \mathrm{Ca}^{2+}=3,40 \mathrm{cmol}_{\mathrm{c}} \mathrm{dm}^{-3}$, $\mathrm{Mg}^{2+}=1,05 \mathrm{cmol}_{\mathrm{c}} \mathrm{dm}^{-3}$ e $\mathrm{Al}^{3+}=0,10 \mathrm{cmol}_{\mathrm{c}} \mathrm{dm}^{-3}$; para o sistema de plantio convencional: $\mathrm{pH}$ (água) $=6,1$, matéria orgânica $=10,1 \mathrm{~g} \mathrm{~kg}^{-1}$, $\mathrm{P}=260 \mathrm{mg} \mathrm{dm}^{-3}, \mathrm{~K}^{+}=157 \mathrm{mg} \mathrm{dm}^{-3}, \mathrm{Ca}^{2+}=$ $3,65 \mathrm{cmol}_{\mathrm{c}} \mathrm{dm}^{-3}, \mathrm{Mg}^{2+}=0,90 \mathrm{cmol}_{\mathrm{c}} \mathrm{dm}^{-3} \mathrm{e} \mathrm{Al}^{3+}=$ $0,075 \mathrm{cmol}_{\mathrm{c}} \mathrm{dm}^{-3}$.

A cultura foi irrigada por gotejamento com emissores de vazão de $1,7 \mathrm{~L} \mathrm{~h}^{-1}$, espaçados de $0,30 \mathrm{~m}$. O manejo da água foi realizado com base na curva característica de água no solo para cada sistema de plantio a 15 e $30 \mathrm{~cm}$ de profundidade, e o controle da lâmina de água foi feito com base na leitura diária de dois tensiômetros instalados nas mesmas profundidades da curva, de modo que mantivesse o solo com a umidade superior a $80 \%$ da água disponivel total. As adubações foram feitas com base na análise química do solo e nas exigências da cultura, através de fertirrigação, utilizando-se $200 \mathrm{~kg} \mathrm{ha}^{-1}$ de $\mathrm{N}, 300 \mathrm{~kg} \mathrm{ha}^{-1} \mathrm{de}$ $\mathrm{P}_{2} \mathrm{O}_{5}$ e $250 \mathrm{~kg} \mathrm{ha}^{-1}$ de $\mathrm{K}_{2} \mathrm{O}$, na forma de sulfato 
de amônia, fosfato de monoamônio (MAP) e cloreto de potássio, respectivamente.

Para evitar o acamamento, as plantas de pimentão foram tutoradas com fitilhos de polietileno. Nas subparcelas com capinas, nos dois sistemas de plantio, o controle das plantas infestantes foi realizado manualmente a cada 14 dias após o transplantio (DAT), e, nas subparcelas com filme de polietileno, as plantas daninhas que surgiram nos orificios onde foram transplantadas as mudas de pimentão foram eliminadas manualmente durante o ciclo da cultura. Os frutos de pimentão da área útil das subparcelas foram colhidos semanalmente, após 65 DAT, sendo utilizado como critério de colheita o início da maturação, quando foi determinada a produtividade, obtida realizando-se o somatório da massa dos frutos colhidos durante o ciclo da cultura na área útil das subparcelas.

Aos $21,42,63,84,105$ e 112 DAT, foram realizadas avaliações de plantas daninhas nos tratamentos sem capinas, por meio de duas amostragens por subparcela, em quadrados vazados de $0,50 \mathrm{~cm}$ de lado. As plantas daninhas foram coletadas ao nivel do solo, contadas e levadas à estufa de circulação forçada de ar a $65{ }^{\circ} \mathrm{C}$ até atingirem massa constante, para determinação da matéria seca.

De cada subparcela foram coletadas três amostras simples, com aproximadamente $300 \mathrm{~g}$ de solo na fileira central, a $10 \mathrm{~cm}$ das plantas de pimentão, na profundidade de $0-10 \mathrm{~cm}$, que foram homogeneizadas para formação de uma amostra composta, para cada época de coleta $(0,21,42,63,84$ e 105 DAT). Após cada coleta, as amostras foram passadas em peneiras com malha de 2,0 $\mathrm{mm}$, acondicionadas em sacos plásticos e mantidas sob refrigeração a $15{ }^{\circ} \mathrm{C}$ até o dia do plaqueamento, para análise da comunidade microbiana.

A quantificação dos microrganismos foi realizada pelo método da diluição seriada e plaqueamento em meio de cultura específico para cada grupo de microrganismos (bactérias, fungos e actinomicetos totais). O método de contagem em placa foi escolhido por ter a grande vantagem de quantificar as células viáveis (Tortora et al., 2006). Para isso, de cada amostra foi retirada uma alíquota de $1 \mathrm{~g}$ de solo, que foi colocada em tubos de ensaio contendo $9 \mathrm{~mL}$ de água destilada esterilizada, que foram homogeneizadas em agitador de tubos tipo vórtex. A partir dessas amostras, realizaram-se diluições seriadas até $10^{-5}$, que foram novamente homogeneizadas para coleta de $100 \mu \mathrm{L}$ de cada diluição e adicionadas em placas de $9,0 \mathrm{~cm}$ de diâmetro contendo os meios de cultura para posterior espalhamento, com o auxílio da alça de Drigalski. As placas foram invertidas e colocadas em estufas tipo $\mathrm{BOD}$, em temperatura de $28 \pm 2{ }^{\circ} \mathrm{C}$, por até seis dias.

Os meios de culturas utilizados variaram em função do tipo de microrganismo. Para a contagem das populações totais de fungos foi utilizado o meio de Martin $\left(1 \mathrm{~g} \mathrm{~K}_{2} \mathrm{HPO}_{4}\right.$ : $0,5 \mathrm{~g}$ de $\mathrm{MgSO}_{4} \cdot 7 \mathrm{H}_{2} \mathrm{O} ; 5 \mathrm{~g}$ de peptona; $10 \mathrm{~g}$ de dextrose; 0,03 g de rosa-bengala; 16 g de ágar; $1.000 \mathrm{~mL}$ de água destilada) (Martin, 1950), acrescido de $0,05 \mathrm{~g} \mathrm{~L}^{-1}$ de tetraciclina. Para bactérias, utilizou-se meio nutriente ágar (ágar nutriente - 23,0 g; água destilada $1.000 \mathrm{~mL}$ ); e para a quantificação da população de actinomicetos, utilizou-se o meio de cultura amido caseína - AC (10 g amido; 0,3 g de caseína; 2,0 g de $\mathrm{KNO}_{3} ; 2 \mathrm{~g}$ de $\mathrm{NaCl} ; 2 \mathrm{~g}$ de $\mathrm{K}_{2} \mathrm{HPO}_{4}: 0,05$ gde $\mathrm{MgSO}_{4} .7 \mathrm{H}_{2} \mathrm{O} ; 0,01$ gde $\mathrm{FeSO}_{4}$. $7 \mathrm{H}_{2} \mathrm{O} ; 16 \mathrm{~g}$ deágar $1.000 \mathrm{~mL}$ de água destilada).

Para cada diluição foram usadas três placas, sendo consideradas para cálculos apenas as diluições que apresentaram de 25 a 250 colônias por placa, pois, quando muitas colônias estão presentes, pode ocorrer saturação, impedindo o crescimento de outras colônias (Tortora et al., 2006). Os valores obtidos foram convertidos em unidades formadoras de colônia por grama de solo (UFCs/g).

Para melhor explicar os resultados obtidos relativos à comunidade microbiana, foram medidas, durante o período experimental, as temperaturas máxima e mínima diária do solo (Figura 1A, B); para isso, instalaram-se, em cada tratamento, sensores tipo termopares de cobre-constantan a $5 \mathrm{~cm}$ de profundidade. Os dados foram coletados a cada 10 minutos e armazenados em dataloggers Campbell CR 1000.

Os dados obtidos foram submetidos à análise de variância pelo teste $\mathrm{F}$ a $10 \%$; os efeitos dos sistemas de plantio e das estratégias de controle de plantas daninhas 

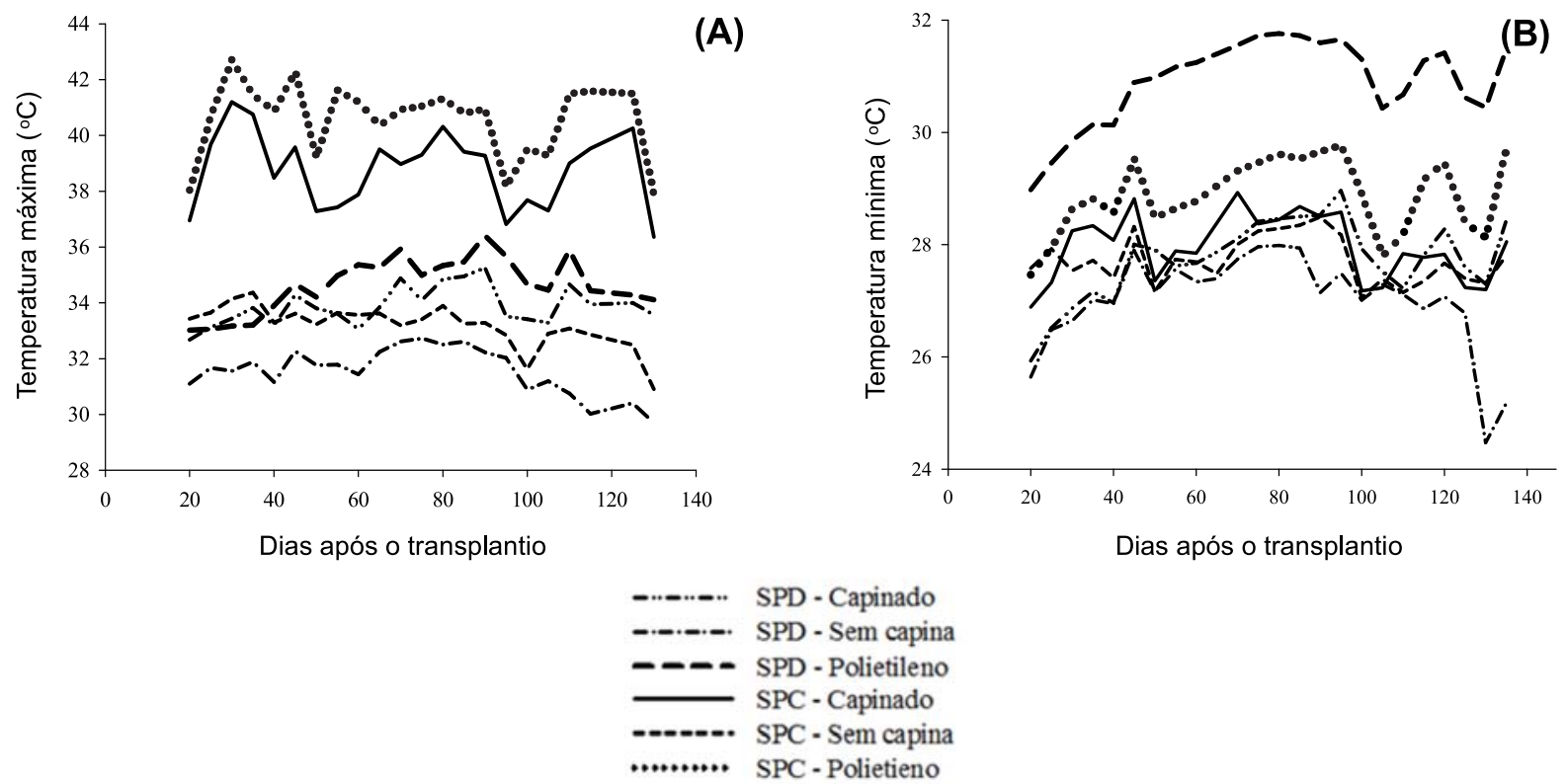

Figura 1 - Temperaturas máxima (A) e mínima (B) diárias do solo durante o ciclo da cultura do pimentão, em função de estratégias de manejo de plantas daninhas e coberturas do solo nos sistemas de plantio direto (SPD) e convencional (SPC). Mossoró-RN, UFERSA, 2010/2011.

sobre a comunidade microbiana e a interação entre os fatores mencionados foram avaliados pelo teste de Tukey a $10 \%$ de probabilidade, com valores transformados em $\sqrt{\mathrm{x}+1}$ ", visando atender às pressuposições da análise de variância, ao passo que os dados relativos à comunidade microbiana ao longo do ciclo do pimentão foram apresentados de forma descritiva, devido à falta de ajuste de modelos de regressão.

\section{RESULTADOS E DISCUSSÃO}

A população e o acúmulo de matéria seca das plantas daninhas ao longo do ciclo variaram em função dos sistemas de plantio, conforme pode ser observado na Figura 2A, B, onde se verifica maior densidade de plantas infestantes no plantio convencional (SPC), principalmente aos 20 dias após o transplantio (DAT), com mais de 500 plantas $\mathrm{m}^{-2}$, contrastando com uma baixa infestação no plantio direto (SPD), o que pode ser atribuído à barreira física imposta pela palhada, a qual impede a passagem de luz, reduzindo a germinação de sementes fotoblásticas positivas e a emergência de plântulas de espécies que não conseguem transpor a cobertura morta (Silva et al., 2009). Isso corrobora outros trabalhos, que também evidenciaram menor incidência de plantas daninhas no sistema de plantio direto (Nascimento et al., 2011; Teófilo et al., 2012).

Aos 60 DAT, verificou-se incremento na população e densidade de plantas no SPD, enquanto no SPC houve incremento na massa seca e decréscimo na densidade de plantas em relação à avaliação anterior, fato que também ocorre aos 100 DAT para os dois sistemas de plantio. Essa redução na densidade de plantas se deve à predominância de espécies de maior porte, como caruru (Amaranthus spinosus), jitirana (Merremia aegyptia), erva-de-rola (Croton lobatus) e melão-de-são-caetano (Momordica charantia), que promovem intensa competição intra e interespecífica, reduzindo a população de espécies menos competitivas.

A cobertura do solo com palhada no plantio direto, assim como a presença das plantas daninhas nas subparcelas sem capinas, nos dois sistemas de plantio, proporcionaram intenso sombreamento no solo, reduzindo o aquecimento, em relação ao solo mantido no limpo por meio de capinas e cobertura com filme de polietileno no sistema de plantio convencional (SPC), como pode ser verificado na Figura 1A. O filme de polietileno sobre a 
palhada, no sistema de plantio direto, apresentou menor elevação da temperatura em relação ao respectivo tratamento no SPC. No entanto, durante a noite, a palhada sob o filme de polietileno no sistema de plantio direto (SPD) funcionou como isolante térmico, diminuindo a perda de calor, fazendo com que a temperatura mínima diária fosse superior à das demais coberturas de solo avaliadas (Figura 1B), resultando em menor amplitude térmica.

Maior produtividade de pimentão foi verificada no tratamento com capinas no SPD (Tabela 1), o que se deve à ausência da competição exercida pelas plantas infestantes em relação aos tratamentos sem capinas nos dois sistemas de plantio e à faixa de temperatura mais adequada para a cultura, com menor aquecimento do solo, em comparação aos tratamentos com filme de polietileno nos dois sistemas de plantio e com capinas, sem cobertura do solo, no SPC.

Segundo Pádua et al. (1984) e Lorentz (2004), durante o florescimento a temperatura diurna do solo deve estar entre $21^{\circ} \mathrm{C}$ e $27^{\circ} \mathrm{C}$, e a noturna, entre $18{ }^{\circ} \mathrm{C}$ e $20^{\circ} \mathrm{C}$, por favorecer a boa formação dos frutos. Ainda segundo esses autores, temperatura do solo acima de $30^{\circ} \mathrm{C}$ reduz o crescimento radicular e provoca o abortamento de flores.

O número de unidades formadoras de colônias (UFCs) de bactérias, fungos e actinomicetos, no solo, variou ao longo do ciclo da cultura do pimentão, tanto para as estratégias de manejo de plantas daninhas quanto para
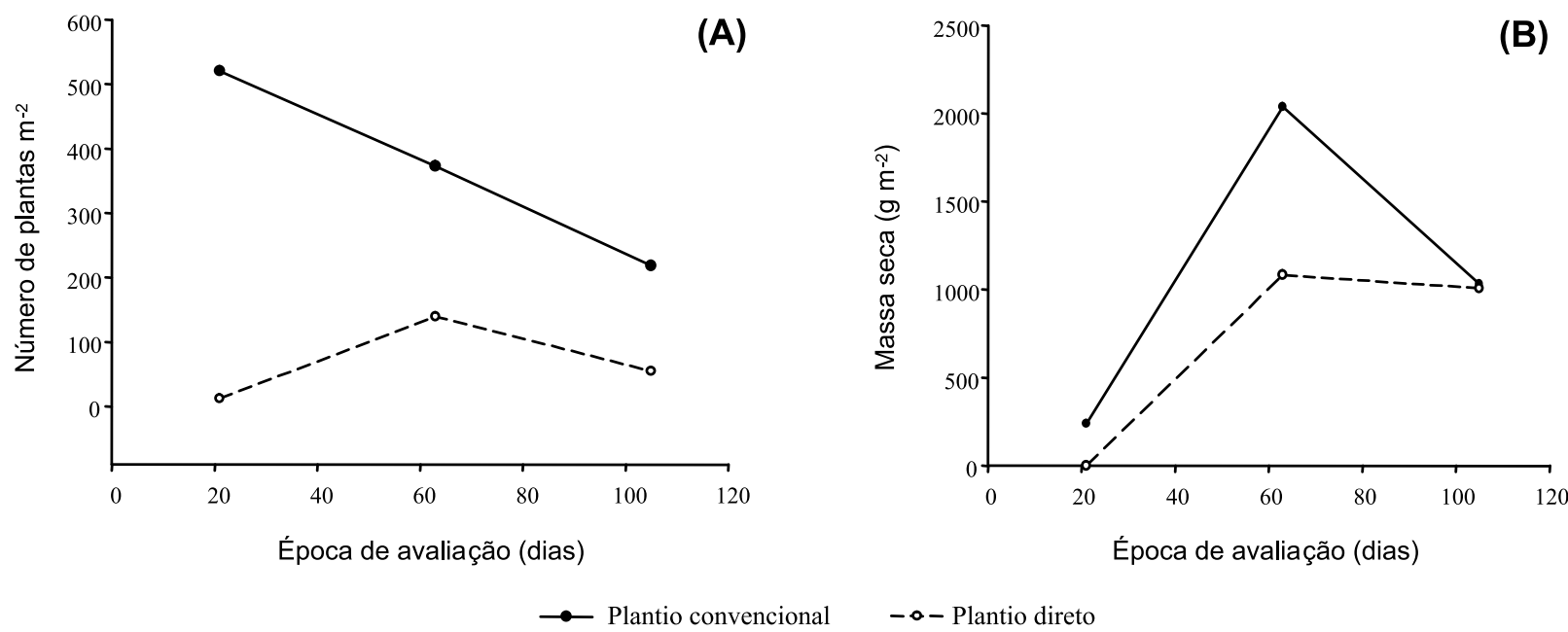

Figura 2 - Densidade (A) e matéria seca (B) de plantas daninhas durante o ciclo do pimentão, em função dos sistemas de plantio e da ausência de capina. Mossoró - RN, UFERSA, 2010/2011.

Tabela 1 - Produtividade da cultura do pimentão em função de estratégias de manejo de plantas daninhas nos sistemas de plantio direto e convencional. Mossoró-RN, UFERSA, 2010/2011

\begin{tabular}{|c|l|c|c|}
\hline \multirow{2}{*}{ Sistema de plantio } & \multicolumn{1}{|c|}{ Sistema de manejo } & $\begin{array}{c}\text { Plantio direto } \\
\left(\mathrm{t} \mathrm{ha}^{-1}\right)\end{array}$ & $\begin{array}{c}\text { Plantio convenc. } \\
\left(\mathrm{t} \mathrm{ha}^{-1}\right)\end{array}$ \\
\hline \multirow{3}{*}{ Plantio direto } & Polietileno preto & $10,42 \mathrm{bA}$ & $8,45 \mathrm{aA}$ \\
\cline { 2 - 4 } & Capinado & $38,41 \mathrm{aA}$ & $12,18 \mathrm{aB}$ \\
\cline { 2 - 4 } & Sem capina & $1,93 \mathrm{cA}$ & $0,78 \mathrm{bA}$ \\
\hline & & 16,92 & 7,13 \\
\hline
\end{tabular}

Nas colunas, letras minúsculas comparam as estratégias de manejo de plantas daninhas dentro de cada sistema de plantio pelo teste de Tukey ( $\leq 0,05)$, e nas linhas, letras maiúsculas comparam sistemas de plantio dentro de cada estratégia de manejo de plantas daninhas pelo teste $\mathrm{F}(\mathrm{p} \leq 0,05)$. 
os sistemas de preparo do solo (Figura 3A, B, C). Diante disso, procedeu-se, para cada grupo de microrganismos, a desdobramentos das interações entre os sistemas de plantio e as estratégias de manejo de plantas daninhas dentro de cada época de amostragem do solo (Tabela 2).

Na primeira avaliação, quando o solo foi coletado no dia do transplantio das mudas de pimentão, verificou-se apenas efeito dos sistemas de plantio sobre as populações de bactérias, fungos e actinomicetos, com menor número de UFCs por grama de solo no SPC em relação ao SPD, o que se deve ao revolvimento do solo com aração e gradagem no SPC, realizado oito dias antes do transplantio, propiciando condições desfavoráveis à comunidade microbiana, tanto pela exposição à radiação solar, que eleva a temperatura e a perda de umidade do solo no intervalo de tempo entre o revolvimento e o transplantio, quanto pelo efeito mecânico ao desagregar as partículas de solo, que pode causar danos às estruturas vegetativas de determinados microrganismos. Segundo Calderón et al. (2001), o revolvimento do solo no SPC pode causar o rompimento das hifas, prejudicando o desenvolvimento da população fúngica.

Nos tratamentos com SPD, o solo foi mantido com cobertura morta e sem perturbação na sua estrutura, oferecendo condições mais adequadas à sobrevivência da comunidade microbiana, com menor variação térmica ao longo do dia (Figura 1A, B). Além da menor variação térmica, o SPD melhora o teor de umidade do solo e o acúmulo de matéria orgânica (Souza \& Resende, 2006), que são estimulantes ao desenvolvimento e reprodução de microrganismos. É importante ressaltar que a área das parcelas vem sendo cultivada nos respectivos sistemas de plantio há quatro anos, o que também pode ter propiciado ao SPD condições mais adequadas ao estabelecimento da comunidade microbiana, como, por exemplo, a elevação no teor de matéria orgânica em relação ao SPC.

Não houve diferença no número de UFCs para as diferentes comunidades microbianas entre os sistemas de manejo de plantas daninhas no dia do transplantio, dentro de cada sistema de plantio (Tabela 2), certamente, devido ao fato de ainda não haver infestação
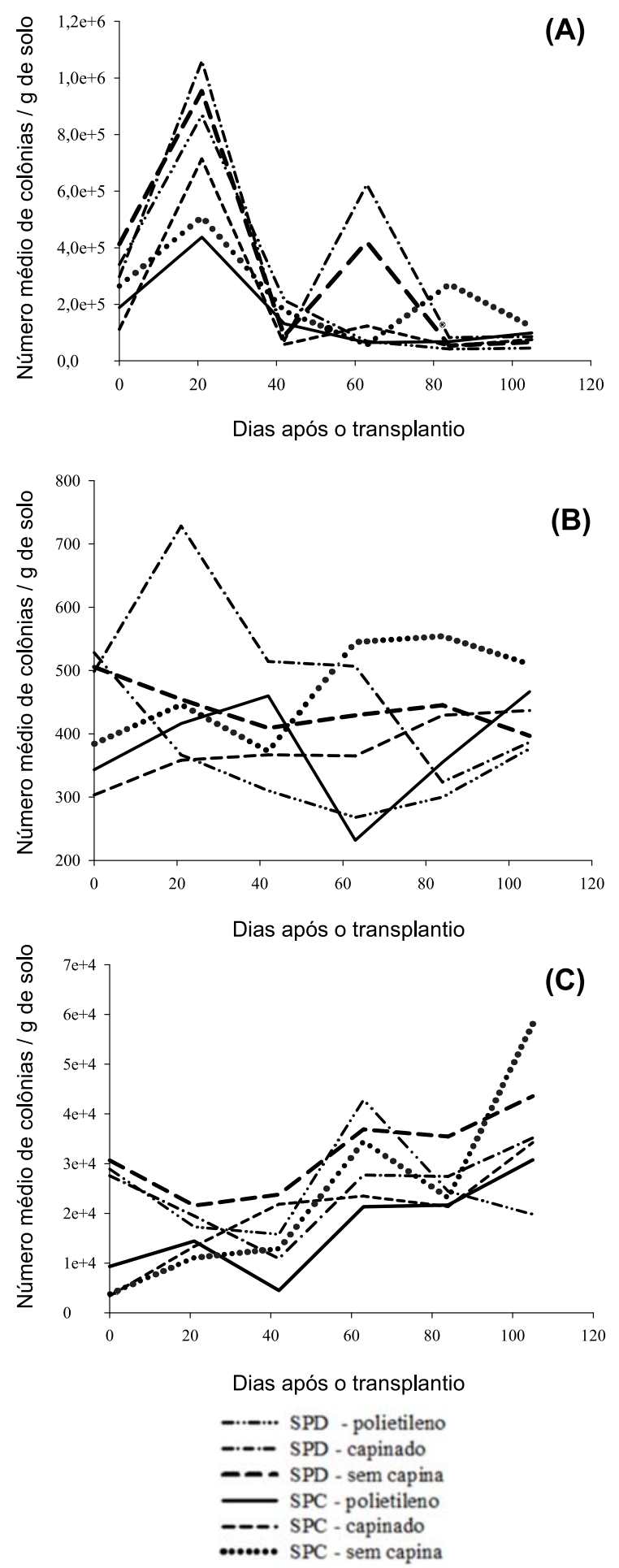

Figura 3 - Número de unidades formadoras de colônias (UFCs) de bactérias (A), fungos (B) e actinomicetos (C) por grama de solo, ao longo do ciclo da cultura do pimentão cultivado nos sistemas de plantio direto (SPD) e convencional (SPC), em diferentes estratégias de manejo de plantas daninhas (filme de polietileno, com capinas e sem capina). Mossoró - RN, UFERSA, 2010/2011. 
de plantas daninhas nos tratamentos sem capinas e de o solo ainda não estar coberto pelo filme de polietileno no momento da coleta.
Na segunda avaliação, aos 21 DAT, observou-se incremento no número de UFCs de bactérias por grama de solo, em relação ao dia do transplantio, para todos os tratamentos

Tabela 2 - Número médio de colônias de bactérias, fungos e actinomicetos por grama de solo cultivado com pimentão nos sistemas de plantio direto e convencional, em diferentes estratégias de manejo de plantas daninhas. Mossoró-RN, UFERSA, 2010/2011

\begin{tabular}{|c|c|c|c|c|c|c|c|}
\hline \multirow{2}{*}{$\begin{array}{c}\text { Sistema } \\
\text { de } \\
\text { plantio }\end{array}$} & \multirow{2}{*}{$\begin{array}{c}\text { Manejo de } \\
\text { plantas } \\
\text { daninhas }\end{array}$} & \multicolumn{6}{|c|}{$\begin{array}{c}\text { Épocas de avaliação } \\
\text { Dias após o transplantio }\end{array}$} \\
\hline & & 0 & 21 & 42 & 63 & 84 & 105 \\
\hline \multicolumn{8}{|c|}{ Bactérias } \\
\hline \multirow{6}{*}{ Direto } & \multirow{2}{*}{$\begin{array}{l}\text { Filme } \\
\text { polietil. }\end{array}$} & $582,96 \mathrm{aA}^{\frac{1}{1 /}}$ & $903,45 \mathrm{aA}$ & $455,47 \mathrm{aA}$ & $259,54 \mathrm{bA}$ & $201,86 \mathrm{bA}$ & $211,71 \mathrm{bB}$ \\
\hline & & $(340.833,3)$ & $(867.777,8)$ & $(214.222,2)$ & $(69.166,7)$ & $(42.083,3)$ & $(45.416,7)$ \\
\hline & \multirow{2}{*}{$\begin{array}{l}\text { Com } \\
\text { capinas }\end{array}$} & $529,61 \mathrm{aA}$ & $1.025,62 \mathrm{aA}$ & $235,86 \mathrm{aA}$ & $753,02 \mathrm{aA}$ & $285,93 \mathrm{aA}$ & $291,28 \mathrm{aA}$ \\
\hline & & $(297.777,8)$ & $(1.060 .000,0)$ & $(58.450,0)$ & $(623.333,3)$ & $(82.666,7)$ & $(86.083,3)$ \\
\hline & \multirow{2}{*}{$\begin{array}{c}\text { Sem } \\
\text { capinas }\end{array}$} & $640,05 \mathrm{aA}$ & $963,74 \mathrm{aA}$ & $293,01 \mathrm{aA}$ & $601,90 \mathrm{aA}$ & $226,27 \mathrm{abB}$ & $258,22 \mathrm{abB}$ \\
\hline & & $(412.916,7)$ & $(953.333,3)$ & $(88.333,3)$ & $(420.750,0)$ & $(54.222,2)$ & $(66.833,3)$ \\
\hline \multirow{6}{*}{ Conv. } & \multirow{2}{*}{$\begin{array}{l}\text { Filme } \\
\text { polietil. }\end{array}$} & $395,59 \mathrm{aB}$ & $644,17 \mathrm{aB}$ & $347,94 \mathrm{aA}$ & $253,15 \mathrm{aA}$ & $261,79 \mathrm{bA}$ & 313,32abA \\
\hline & & $(188.583,3)$ & $(437.500,0)$ & $(131.666,7)$ & $(64.916,7)$ & $(68.750,0)$ & $(99.333,3)$ \\
\hline & \multirow{2}{*}{$\begin{array}{l}\text { Com } \\
\text { capinas }\end{array}$} & $326,40 \mathrm{aB}$ & $814,75 \mathrm{aB}$ & $238,32 \mathrm{bA}$ & $337,84 \mathrm{aB}$ & $227.55 \mathrm{bA}$ & $272,54 \mathrm{bA}$ \\
\hline & & $(112.000,0)$ & $(713.777,7)$ & $(58.666,6)$ & $(123.583,3)$ & $(53.111,1)$ & $(75.750,0)$ \\
\hline & \multirow{2}{*}{$\begin{array}{c}\text { Sem } \\
\text { capinas }\end{array}$} & $485,26 \mathrm{aB}$ & $696,44 \mathrm{aB}$ & $397,01 \mathrm{aA}$ & $234,74 \mathrm{aB}$ & $519,15 \mathrm{aA}$ & $344,59 \mathrm{aA}$ \\
\hline & & $(264.444,4)$ & $(509.166,6)$ & $(176.916,6)$ & $(57.250,0)$ & $(271.111,1)$ & $(120.50,0)$ \\
\hline \multicolumn{2}{|c|}{$\mathrm{CV}(\%)$} & 30,944 & 21,162 & 30,015 & 36,752 & 16,611 & 13,382 \\
\hline \multicolumn{8}{|c|}{ Fungos } \\
\hline \multirow{6}{*}{ Direto } & \multirow{2}{*}{$\begin{array}{l}\text { Filme de } \\
\text { polietil. }\end{array}$} & $22,96 \mathrm{aA}^{1 /}$ & $19,13 \mathrm{bA}$ & $17,52 \mathrm{aA}$ & $16,37 \mathrm{bA}$ & $17,24 \mathrm{aA}$ & $19,27 \mathrm{aA}$ \\
\hline & & $(528,33)$ & $(366,67)$ & $(310,00)$ & $(267,78)$ & $(300,00)$ & $(376,67)$ \\
\hline & \multirow{2}{*}{$\begin{array}{c}\text { Com } \\
\text { capinas }\end{array}$} & $22,00 \mathrm{aA}$ & $26,44 \mathrm{aA}$ & $21,40 \mathrm{aA}$ & $22,42 \mathrm{aA}$ & $17,67 \mathrm{aA}$ & $19,05 \mathrm{aA}$ \\
\hline & & $(487,50)$ & $(728,33)$ & $(514,17)$ & $(506,67)$ & $(323,75)$ & $(386,67)$ \\
\hline & \multirow{2}{*}{$\begin{array}{c}\text { Sem } \\
\text { capinas }\end{array}$} & $21,68 \mathrm{aA}$ & $20,86 \mathrm{bA}$ & $20,14 \mathrm{aA}$ & $19,49 \mathrm{aA}$ & $21,09 \mathrm{aA}$ & $19,67 \mathrm{aA}$ \\
\hline & & $(474,44)$ & $(454,17)$ & $(408,89)$ & $(429,17)$ & $(445,00)$ & $(396,67)$ \\
\hline \multirow{6}{*}{ Conv. } & \multirow{2}{*}{$\begin{array}{l}\text { Filme de } \\
\text { polietil. }\end{array}$} & $18,49 \mathrm{aB}$ & $20,37 \mathrm{aA}$ & $21,45 \mathrm{aA}$ & $15,13 \mathrm{bA}$ & $18,76 \mathrm{aA}$ & $21,49 \mathrm{aA}$ \\
\hline & & $(343,33)$ & $(416,25)$ & $(460,00)$ & $(231,67)$ & $(355,00)$ & $(466,67)$ \\
\hline & \multirow{2}{*}{$\begin{array}{l}\text { Com } \\
\text { capinas }\end{array}$} & $17,37 \mathrm{aB}$ & $18,84 \mathrm{aB}$ & $19,06 \mathrm{aA}$ & $19,01 \mathrm{aA}$ & $20,44 \mathrm{aA}$ & $20,77 \mathrm{aA}$ \\
\hline & & $(303,33)$ & $(358,33)$ & $(366,67)$ & $(365,00)$ & $(429,17)$ & $(436,67)$ \\
\hline & \multirow{2}{*}{$\begin{array}{c}\text { Sem } \\
\text { capinas }\end{array}$} & $19,51 \mathrm{aB}$ & $20,96 \mathrm{aA}$ & $19,29 \mathrm{aA}$ & $22,53 \mathrm{aA}$ & $22,54 \mathrm{aA}$ & $22,04 \mathrm{aA}$ \\
\hline & & $(385,00)$ & $(445,83)$ & $(372,22)$ & $(545,00)$ & $(554,17)$ & $(510,00)$ \\
\hline \multicolumn{2}{|c|}{$\mathrm{CV}(\%)$} & 12,25 & 21,024 & 20,86 & 24,86 & 18,67 & 19,27 \\
\hline & & & & micetos & & & \\
\hline & Filme & $169,65 \mathrm{aA}^{1}$ & $109,73 \mathrm{aA}$ & $125.52 \mathrm{abA}$ & $206.34 \mathrm{aA}$ & $155,94 \mathrm{aA}$ & $138,74 \mathrm{bB}$ \\
\hline & Polietil. & $(28.916,7)$ & $(17.275,0)$ & $(15.777,8)$ & $(42.833,3)$ & $(24.444,4)$ & $(19.777,8)$ \\
\hline $\mathrm{D}$ & Com & $165,99 \mathrm{aA}$ & $138,77 \mathrm{aA}$ & $103.60 \mathrm{bB}$ & $165.78 \mathrm{bA}$ & $165,23 \mathrm{aA}$ & $179,85 \mathrm{abA}$ \\
\hline Direto & capinas & $(27.555,6)$ & $(19.458,3)$ & $(10.900,0)$ & $(27.708,3)$ & $(27.416,7)$ & $(35.166,7)$ \\
\hline & Sem & $174,36 \mathrm{aA}$ & $145,58 \mathrm{aA}$ & $151.50 \mathrm{aA}$ & $190.23 \mathrm{abA}$ & $187,53 \mathrm{aA}$ & $207,67 \mathrm{aA}$ \\
\hline & capinas & $(30.666,7)$ & $(21.541,7)$ & $(23.777,8)$ & $(36.888,9)$ & $(35.416,7)$ & $(43.583,3)$ \\
\hline & Filme & $90,35 \mathrm{aB}$ & $119,99 \mathrm{aA}$ & $66,64 \mathrm{cB}$ & $146,06 \mathrm{bB}$ & $146,28 \mathrm{aA}$ & $173,41 \mathrm{bA}$ \\
\hline & polietil. & $(9.352,8)$ & $(14.416,7)$ & $(45.00,0)$ & $(21.333,3)$ & $(21.666,7)$ & $(30.750,0)$ \\
\hline$C$ & Com & $56,88 \mathrm{aB}$ & $113,49 \mathrm{aA}$ & $146.64 \mathrm{aA}$ & $151.91 \mathrm{abA}$ & $145,80 \mathrm{aA}$ & $183,57 \mathrm{abA}$ \\
\hline Conv. & capinas & $(3.383,3)$ & $(13.333,3)$ & $(21.833,3)$ & $(23.458,3)$ & $(21.333,3)$ & $(34.250,0)$ \\
\hline & Sem & $61,31 \mathrm{aB}$ & $103,04 \mathrm{aA}$ & $112.45 \mathrm{bB}$ & $184.98 \mathrm{aA}$ & $151,45 \mathrm{aA}$ & $240,15 \mathrm{aA}$ \\
\hline & capinas & $(3.766,7)$ & $(11.083,3)$ & $(12.888,9)$ & $(34.444,4)$ & $(23.111,1)$ & $(58.222,2)$ \\
\hline $\mathrm{C}$ & $\%$ & 15,56 & 32,61 & 16,43 & 12,07 & 15,80 & 20,72 \\
\hline
\end{tabular}

1/ Para cada grupo de microrganismos, nas colunas, letras minúsculas comparam as estratégias de manejo de plantas daninhas dentro de cada sistema de plantio pelo teste de Tukey a $10 \%$ de probabilidade, e letras maiúsculas comparam os sistemas de plantio dentro de cada estratégia de manejo de plantas daninhas pelo teste de F a $10 \%$ de probabilidade. Dados transformados em “ $\sqrt{\mathrm{x}+1}$ ”, com os valores reais entre parênteses. 
avaliados (Figura 3A), o que se deve ao suprimento de água a partir desse momento. Esse fato, por si só, já influencia positivamente o crescimento microbiano, além de promover a decomposição do material vegetal presente no solo, liberando substratos para o desenvolvimento da comunidade microbiana. No entanto, assim como por ocasião do transplantio, o SPD manteve população superior à do SPC, independentemente da estratégia de manejo de plantas daninhas empregada (Tabela 2).

Vargas et al. (2004) observaram maior crescimento da biomassa bacteriana no SPD em relação ao SPC, o qual, segundo SalinasGarcia et al. (1997), é favorecido pela maior disponibilidade de compostos nitrogenados na superficie do solo, visto que o nitrogênio é um dos elementos essenciais ao crescimento microbiano, por ser utilizado para diversas funções, como sinteses de proteinas, DNA, RNA e ATP (Tortora et al., 2006).

Aos 42 DAT, observou-se queda acentuada no número de UFCs de bactérias em relação à avaliação realizada aos $21 \mathrm{DAT}$, em todos os tratamentos (Figura 3A), sem diferenças entre os sistemas de plantio e manejo de plantas daninhas (Tabela 2), o que pode estar relacionado a uma condição de ambiente desfavorável à comunidade bacteriana nesse período, provavelmente causada por alguma prática de manejo ou mesmo devido ao antagonismo proporcionado por outros organismos do solo, os quais, segundo Stanford et al. (2005), produzem compostos gasosos e antibióticos que podem inibir o crescimento e desenvolvimento de outros.

A partir dos 42 DAT até o final do ciclo da cultura, as UFCs de bactérias não sofrem grandes variações, embora se observe aos 63 DAT, no sistema de plantio direto, maior número de UFCs nos tratamentos com capinas e sem capinas e, aos 84 DAT, no tratamento sem capinas no SPC (Tabela 2), o que provavelmente se deve à decomposição das plantas daninhas, que ocorreram em grande intensidade neste tratamento (Figura 2), disponibilizando maior quantidade de substrato, além das condições de microclima favoráveis, devido à intensa cobertura do solo pelas plantas infestantes.

A redução do número de UFCs de bactérias no final do ciclo da cultura (Figura 3A) se deve, provavelmente, à redução da disponibilidade de substrato no solo, ou seja, parte do material já havia sido decomposta e pode ter ocorrido menor disponibilidade dos nutrientes. Apesar da grande flutuação da população de bactérias nesse período, de modo geral, foi observado que o sistema de plantio direto propiciou condições mais favoráveis ao referido microrganismo.

Diferentemente das bactérias, aos 21 DAT, as UFCs de fungos foram influenciadas tanto pelos sistemas de plantio quanto pelas estratégias de plantas daninhas. Maior número de UFCs, no SPD, foi verificado no tratamento com capinas, em relação aos tratamentos com filme de polietileno e sem capinas, alcançando indice superior também ao do tratamento com capinas no SPC; nesse sistema de plantio, não houve variação entre as estratégias de manejo de plantas daninhas (Tabela 2).

Observou-se, nos tratamentos com e sem capinas no SPD e em todas as estratégias de manejo de plantas daninhas no SPC, incremento no número de colônias fúngicas em relação à avaliação anterior (Figura 3A), devido ao restabelecimento da umidade do solo com irrigação a partir do transplantio e à decomposição do material vegetal incorporado no solo. A cobertura do solo com filme de polietileno no SPD reduziu de forma acentuada a população fúngica no mesmo periodo, possivelmente devido ao aumento da temperatura média diária nesse tratamento com a colocação do filme, uma vez que, apesar de a temperatura máxima diária não ser tão elevada (Figura 1A), durante a noite, não há perda de calor, mantendo a temperatura minima em patamares superiores aos dos demais tratamentos (Figura 1B).

Para Tortora et al. (2006), a temperatura é um dos fatores preponderantes para o crescimento de microrganismos, influenciando diretamente as reações fisiológicas e características físico-químicas (volume, pressão, difusão e viscosidade) que afetam as células. Stanford et al. (2005) relatam que, embora o choque térmico possa provocar quebra de dormência e estimular a atividade microbiana, temperatura fora da faixa ótima provoca depressão da população e suas funções, em valores superiores a $50 \%$, podendo atingir $99 \%$. 
Aos 42 DAT, observou-se queda acentuada no número de colônias de fungos no sistema de plantio direto com capinas em relação à avaliação realizada aos 21 DAT, sem grandes variações nos demais tratamentos (Figura 3B), não se verificando efeito entre os sistemas de plantio, assim como entre os sistemas de manejo de plantas daninhas (Tabela 2).

A partir dos 42 DAT, o número de UFCs manteve-se constante para a maioria dos tratamentos, com exceção da cobertura com filme de polietileno nos dois sistemas de plantio, que apresentou número de UFCs fúngicas inferior ao das demais combinações entre sistemas de plantio e manejo de plantas daninhas aos 63 DAT e ao tratamento sem capinas no SPC, com aumento expressivo no número de UFCs a partir dos 63 DAT até o final do ciclo (Figura 3B). Isso se deve, possivelmente, à grande infestação de plantas daninhas neste tratamento (Figura 2A), que inicia o processo de senescência, evidenciada pela queda de biomassa da parte aérea (Figura 2B), aumentando a disponibilidade de material orgânico na superfície do solo ou mesmo no solo com a decomposição do sistema radicular de plantas de ciclo mais curto.

Nos dois últimos períodos de avaliação, 84 e 105 DAT, não foi verificado efeito dos sistemas de plantio nem dos sistemas de manejo de plantas daninhas sobre a população de fungos no solo, o que pode estar diretamente relacionado à redução da cobertura do solo com palhada no SPD, devido à decomposição e à estabilização do solo no SPC ao longo do ciclo da cultura.

Não houve diferença no número de UFCs de actinomicetos aos 21 DAT entre os sistemas de plantio e as estratégias de manejo de plantas daninhas (Tabela 2). Entretanto, observou-se, nos tratamentos envolvendo o SPC, aumento no número de colônias de actinomicetos em relação à avaliação anterior, possivelmente devido à reconstituição da população, após a desestruturação do solo, favorecida pela manutenção da umidade em condições favoráveis e pela decomposição do material vegetal incorporado por ocasião da aração e gradagem, ao passo que para os tratamentos mantidos no SPD houve discreta redução das UFCs de actinomicetos (Figura 3C).
Aos 42 DAT, quando se compararam os sistemas de manejo de plantas daninhas no SPD, maior população de actinomicetos foi verificada no tratamento sem capinas, enquanto no SPC o maior número de colônias foi observado no tratamento com capinas (Tabela 2). Nas avaliações posteriores, verificou-se, para todos os tratamentos avaliados, elevação gradativa no número de colônias até 105 DAT (Figura 3C), com exceção do solo coberto com filme de polietileno no SPD, que apresentou incremento no número de colônias até 63 DAT, seguido de queda até 105 DAT, não havendo grande variação populacional de actinomicetos entre as combinações envolvendo sistemas de preparo do solo e estratégias de manejo de plantas daninhas.

No entanto, aos 105 DAT, os tratamentos sem capinas que apresentaram grande infestação de plantas daninhas se destacaram em relação aos demais, nos dois sistemas de plantio, em virtude da condição de microclima favorável, com menor aquecimento do solo (Figura 1A), devido ao sombreamento proporcionado pelas plantas infestantes, além da deposição e decomposição do material originário da senescência de folhas e/ou de plantas inteiras, inclusive o sistema radicular, que completaram seu ciclo. Isso demonstra a importância da cobertura vegetal sobre o solo durante o período de pousio, propiciando condições favoráveis para a comunidade microbiana, além de outros benefícios, como ciclagem de nutrientes e proteção contra a ação da erosão (Silva \& Silva, 2007), embora algumas espécies possam ser hospedeiras alternativas de patógenos causadores de doenças em culturas.

O número de UFCs decresceu na seguinte ordem: bactérias, actinomicetos e fungos (Figura 3A, B, C e Tabela 2), corroborando os relatos de Tortora et al. (2006), que afirmam que os organismos mais numerosos no solo são as bactérias e que estas são grandes produtoras de antibióticos, promotoras de crescimento em plantas e contribuem positivamente no desenvolvimento de culturas, sendo todos esses microrganismos desfavorecidos pela cobertura do solo com filme de polietileno, nos dois sistemas de plantio, devido à maior elevação da temperatura do solo (Figura 1A, B). 
Foram constatados, em diversas plantas de pimentão dos tratamentos com filme de polietileno, no sistema de plantio convencional, danos provocados pelo fungo fitopatogênico Macrophomina phaseolina (Tassi) Goidanich, que, embora não tenha sido uma variável avaliada, foi confirmada através de isolamentos em meio de cultura. É importante ressaltar que M. phaseolina é um patógeno habitante do solo termotolerante, agente causal de podridões de raízes e caules, bastante difundido em áreas agricultáveis e que infecta mais de 500 espécies de plantas em mais de 100 famílias em todo o mundo (Mihail, 1992).

No Brasil, esse patógeno tem apresentado prejuízos consideráveis em diversas culturas, como algodão, feijão-caupi, gergelim, girassol, melão, milho, pimentão, soja, entre outras (Kimati et al., 2005). Esse fitopatógeno pode ter sido favorecido, no referido tratamento, pelos cultivos anteriores com melão, milho e feijão-caupi, todas estas hospedeiras de M. phaseolina (Kimati et al., 2005), e também pelas elevadas temperaturas do solo, que favorecem o seu desenvolvimento, já que é considerado um microrganismo tolerante a altas temperaturas (Basseto et al., 2011).

As inúmeras transformações biológicas que ocorrem no solo, sob os diferentes manejos, proporcionam liberação de diferentes substâncias, que podem tanto estimular o desenvolvimento de microrganismos como inibir alguns grupos (Stanford et al., 2005). Isso pode ser refletido em oscilações na comunidade microbiana do solo ao longo do desenvolvimento da cultura, tanto quantitativa quanto qualitativamente. Substâncias são liberadas a todo momento associadas à umidade e variações nas temperaturas, modificando o ambiente constantemente e resultando em fatos dificeis de explicar, já que cada microrganismo tem a sua particularidade, havendo diferenças inclusive dentro de um mesmo gênero. Desse modo, o uso de práticas agrícolas, como as que permitem a cobertura vegetal do solo, geralmente resulta na melhoria da produtividade, associada com qualidade e sustentabilidade; contudo, muitos fatores ainda precisam ser estudados, a fim de explicar as possiveis interações desses microrganismos no solo e destes com as diferentes espécies de plantas cultivadas.
Diante do exposto, pode-se concluir que a comunidade microbiana no solo variou durante o ciclo da cultura do pimentão, sendo influenciada pelos dois sistemas de plantio e pelas estratégias de manejo de plantas daninhas, apresentando em todas as avaliações a seguinte ordem decrescente: bactérias, actinomicetos e fungos; o preparo do solo no plantio convencional reduziu a população microbiana no solo; a elevação da temperatura do solo nos tratamentos com filme de polietileno e solo sem cobertura com capinas desfavoreceu a comunidade microbiana; e a cobertura do solo com plantas daninhas ou palhada reduziu o aquecimento do solo, favorecendo a comunidade microbiana.

\section{LITERATURA CITADA}

ANDREOLA, F.; FERNANDES, S. A. P. Microbiota do solo na agricultura orgânica e no manejo das culturas. In:

SILVEIRA, A. P. D.; FREITAS, S. S. Microbiota do solo e qualidade ambiental. Campinas: Instituto Agronômico, 2007. p. 21-38.

BASSETO, M. A. et al. Efeitos da simulação da solarização do solo com materiais vegetais sobre o crescimento micelial de fungos fitopatogênicos habitantes do solo. Summa

Phytopathol., v. 37, n. 3, p. 116-120, 2011.

BONANOMI, G. et al. Soil solarization with biodegradable materials and its impact on soil microbial communities. Soil Biol. Biochem., v. 40, n. 8, p. 1989-1998, 2008.

CALDERÓN, F. J. et al. Short-term dynamics of nitrogen, microbial activity, and phospholipid fatty acids after tillage. Soil Sci. Soc. Am. J., v. 65, n. 1, p. 118-126, 2001.

COELHO, M. E. H. et al. Coberturas do solo sobre a amplitude térmica e a produtividade de pimentão.

Planta Daninha, v. 31, n. 2, p. 369-378, 2013.

FRANCHINI, J. C. et al. M. Microbiological parameters as indicators of soil quality under various soil management and crop rotation systems in Southern Brazil. Soil Tillage Res., v. 92, n. 1/2, p. 18-29, 2007.

FURLANI, C. E. A. et al. Temperatura do solo em função do preparo do solo e do manejo da cobertura de inverno. R. Bras. Ci. Solo, v. 32, n. 1, p. 375-380, 2008.

KIMATI, H. et al. Manual de fitopatologia: doenças das plantas cultivadas. 4.ed. São Paulo: Agronômica Ceres, 2005. v. 2. $663 \mathrm{p}$.

Planta Daninha, Viçosa-MG, v. 32, n. 3, p. 543-554, 2014 
LORENTZ, L. H. Variabilidade da produção de frutos de pimentão em estufa plástica relacionada com técnicas experimentais. 2004. 82 f. Dissertação (Mestrado em Melhoramento Genético) - Universidade Federal de Santa Maria, Santa Maria, 2004.

MIHAIL, J. D. Macrophomina. In: SINGLETON, L. L.; MIHAIL, J. D.; RUSH, C. M. Methods for research on soilborne phytopathogenic fungi. St. Paul: APS Press, 1992. p. $134-136$

NASCIMENTO, P. G. M. L. et al. Levantamento fitossociológico das comunidades infestantes em diferentes sistemas de plantio de milho. Agropec. Cient. Semi-Árido, v. 7, n. 3, p. 1-9, 2011.

PÁDUA, J. G. et al. Efeitos climáticos sobre pimentão e pimenta. Inf. Agropec., v. 10, n. 113, p. 11-13, 1984.

SALINAS-GARCIA, J. R.; HONS, F. M.; MATOCHA, J. E. Long-term effects of tillage and fertilization on soil organic matter dynamics. Soil Sci. Soc. Am. J., v. 61, n. 1, p. 152-159, 1997.

SILVA, A. A.; SILVA, J. F. Biologia de plantas daninhas. In: SILVA, A. A.; SILVA, J. F. Tópicos em manejo de plantas daninhas. Viçosa, MG: Universidade Federal de Viçosa, 2007. p. 17-61.

SILVA, A. C.; HIRATA, E. K.; MONQUERO, P. A. Produção de palha e supressão de plantas daninhas por plantas de cobertura, no plantio direto do tomateiro. Pesq. Agropec. Bras., v. 44, n. 1, p. 22-28, 2009.
SILVA, F. A. Produção de milho para ensilagem e espigas verdes em função de períodos de veranico nos sistemas de plantio direto e convencional. 2013. $84 \mathrm{f}$. Tese (Doutorado em Fitotecnia) - Universidade Federal Rural do Semi-Árido,

Mossoró-RN, 2013.

SOUZA, J. L.; RESENDE, P. Manual de horticultura orgânica. 2.ed. Viçosa, MG: Aprenda Fácil, 2006. 843 p.

STANFORD, N. P. et al. Microbiota dos solos tropicais. In: MICHEREFF, S. J.; ANDRADE, D. E. G. T.; MENEZES, M. (Ed.). Ecologia e manejo de patógenos radiculares em solos tropicais. Recife: Imprensa Universitária, 2005. p. 61-92.

TEÓFILO, T. M. S. et al. Eficiência no uso da água e interferência de plantas daninhas no meloeiro cultivado nos sistemas de plantio direto e convencional. Planta Daninha, v. 30, n. 3, p. 547-556, 2012.

TORTORA, G. J.; FUNKE, B. R.; CASE, C. L.

Microbiologia. 8.ed. Porto Alegre: Artmed, 2006. 894 p.

TÓTOLA, M. R.; CHAER, G. M. Microrganismos e processos microbiológicos como indicadores da qualidade dos solos. In: ALVAREZ V., V. H. et al. (Ed.). Tópicos em ciência do solo. Viçosa, MG: Sociedade Brasileira de Ciência do Solo, 2002. v. 2. p. 195-276.

VARGAS, L. K.; SELBACH, P. A.; SÁ, E. L. S. Alterações microbianas no solo durante o ciclo do milho nos sistemas plantio direto e convencional. Pesq. Agropec. Bras., v. 39, n. 8, p. 749-755, 2004. 